\title{
FAKTOR-FAKTOR YANG MEMPENGARUHI SIKAP SUAMI DALAM PENANGANAN KEGAWATDARURATAN OBSTETRI
}

\author{
${ }^{1}$ Etin Rohmatin, ${ }^{2}$ Sariestya Rismawati \\ 1,2 Staf Dosen Poltekkes Kemenkes Tasikmalaya
}

\begin{abstract}
Abstrak
Tujuan untuk mengetahui faktor-faktor yang mempengaruhi sikap suami dalam penanganan kegawatdaruratan obstetri di Puskesmas Indihiang Kota Tasikmalaya tahun 2016. Jenis Penelitian ini termasuk penelitian kuantitatif dengan rancangan crossectional. Analisis yang digunakan pada penelitian ini dengan menggunkan analisis univariat dan bivariat. Teknik statistik yang digunakan untuk menguji hipotesis tersebut adalah Uji Chi-square. Diperoleh jumlah responden sebanyak 26 suami, hasil univariat responden paling banyak terdapat pada kelompok umur 36-40 tahun (27\%), pekerjaan buruh/tani 50\%, pendidikan SMP yaitu sebanyak 11 orang (42\%), tingkat pengetahuan baik (65\%). Hasil uji statistik chi-square tidak ada hubungan signifikan antara tingkat pendidikan, umur, pekerjaan, penghasilan dan pengetahuan dengan pengambilan sikap suami dalam menghadapi kegawatdaruratan obstertri.
\end{abstract}

Kata Kunci : Sikap Suami, Kegawatdaruratan Obstetri.

\section{Abstract}

The purpose to determine the factors that influence the attitude of the husband in the management of obstetric emergency in Tasikmalaya City Health Center Indihiang 2016. This study types including quantitative research with cross-sectional design. The analysis used in this study by using univariate, and bivariate. A statistical technique used to test the hypothesis is Chi-square test. Retrieved number of respondents was 26 husband, the results of the univariate respondents are most numerous in the age group 36-40 years (27\%), employment of workers / peasants 50\%, SMP as many as 11 people (42\%), the level of knowledge of good (65\%). Analysis bivariate statistical test chi square results no significant relationship between the level of education, age, occupation, income and knowledge by taking a stand in the face of emergencies obstertri husband.

Keywords: Attitudes husband, Emergency, Obstetrics.

\section{PENDAHULUAN}

Aspek medis, manajemen pelayanan kesehatan dan sosial budaya dapat menjadi penyebab kematian Ibu dan bayi. Aspek medis seperti: perdarahan, eklamsi dan infeksi, serta aspek kegagalan manajemen pelayanan antara lain skrening kurang baik, peralatan kurang dan kurang baiknya pemantauan ibu dan bayi pada minggu pertama persalinan dianggap hal yang tidak sulit untuk ditanggulangi. Sedangkan aspek non medis seperti status sosial ekonomi yang relative rendah dan faktor sosial budaya yang kurang mendukung merupakan hal yang dinilai tidak mudah untuk diatasi (Paramita dan Pratiwi, 2007).
Menurut Prof. Dinan, tingginya AKI di Indonesia dipengaruhi oleh beberapa hal yang lebih dikenal dengan istilah 4 terlalu dan 3 terlambat, yakni terlalu muda, terlalu tua, terlalu sering melahirkan, terlalu banyak, dan terlambat dalam mencapai fasilitas, terlambat mendapatkan pertolongan, dan terlambat mengenali tanda bahaya kehamilan dan persalinan (Maulana, 2013).

Suami harus siap menjaga istri dan
calon bayinya serta memberikan
kewenangan untuk menggunakannya
apabila terjadi masalah kehamilan. Suami
juga diharapkan mempunyai hubungan
sosial yang baik dengan tetangga yang


mampu membantu mengatasi jika mengalami masalah kegawatdaruratan kebidanan. Suami harus memiliki pengetahuan tentang tanda bahaya kehamilan, persalinan, nifas, dan mengutamakan keselamatan istri. Sehingga diperlukan terobosan-terobosan baru dalam upaya meningkatkan partisipasi suami, namun dengan tetap memperhatikan faktor spesifik yang mempengaruhinya, sehingga dapat menimbulkan kesadaran dan kemauan dari suami untuk lebih memberdayakan diri dalam berbagi tanggung jawab dengan istrinya. Jika merunut pada konsep suami siaga, maka suami harus memiliki sikap siap antar jaga. Jika peran siaga ini dijalankan, diharapkan keterlambatan yang kerap menjadi penyebab kematian ibu melahirkan tidak terjadi. Keterlambatan yang dimaksud mencakup terlambat mengetahui kelainan kehamilan dan persalinan, terlambat memutuskan untuk segera ke fasilitas pelayanan kesehatan, terlambat menerima perawatan yang tepat (Ambarwati, 2009).

Suami biasanya menjadi pemegang keputusan ketika kondisi istri dalam keadaan membutuhkan pertolongan kesehatan segera. Suami juga yang memutuskan transportasi apa yang digunakan untuk mencapai tempat pelayanan kesehatan. Suami dapat menghindari keterlambatan tersebut dengan cara mengenali gejala-gejala persalinan dan persalinan dengan komplikasi (Ambarwati, 2009). Penelitian ini akan menggali mengenai "Faktor-Faktor yang Mempengaruhi Sikap Suami dalam Penanganan Kegawatdaruratan Obstetri di Wilayah Puskesmas Indihiang Kota Tasikmalaya Tahun 2016".

\section{METODE PENELITIAN}

Desain penelitian ini merupakan penelitian kuantitatif dengan dengan pendekatan crossectional. Populasi penelitian adalah seluruh suami dengan ibu hamil yang terdeteksi resiko tinggi di Wilayah Kerja PKM Indihiang Kota
Tasikmalaya. Data penelitian dikumpulkan melalui proses pengisian kuesioner. Kuesioner dibuat oleh peneliti sendiri yang sebelumnya dilakukan uji validitas dan reliabilitas dengan hasil valid dan reliable. Analisis data menggunakan rumus distribusi frekwensi dan uji chi-square. Sebelum mengisi kuesioner, responden diberi penjelasan terkait penelitian, kemudian menandatangani informed consent. Responden boleh menolak atau menyetujui penelitian. Data terkait responden dijaga kerahasiannya.

\section{HASIL PENELITIAN}

Gambaran Karakteristik Responden Penelitian

Tabel 1. Distribusi Frekuensi Tingkat Pendidikan Responden

\begin{tabular}{ccc}
\hline $\begin{array}{c}\text { Tingkat } \\
\text { Pendidikan }\end{array}$ & Frekuensi & $\%$ \\
\hline SD & 8 & 31 \\
\hline SMP & 11 & 42 \\
\hline SMA & 5 & 19 \\
\hline PT/Akademi & 2 & 8 \\
\hline TOTAL & $\mathbf{2 6}$ & $\mathbf{1 0 0}$ \\
\hline
\end{tabular}

Tabel 2. Distribusi Frekuensi Jarak Rumah Responden ke Bidan

\begin{tabular}{ccc}
\hline $\begin{array}{c}\text { Jarak } \\
\text { (meter) }\end{array}$ & Frekuensi & $\%$ \\
\hline$\leq 1.000$ & 22 & 85 \\
\hline $1.001-2.000$ & 3 & 12 \\
\hline $2.001-3.000$ & 1 & 4 \\
\hline TOTAL & $\mathbf{2 6}$ & $\mathbf{1 0 0}$ \\
\hline
\end{tabular}

Tabel 3. Distribusi Frekuensi Jarak Rumah Responden ke Dokter

\begin{tabular}{ccc}
\hline $\begin{array}{c}\text { Jarak } \\
\text { (meter) }\end{array}$ & Frekuensi & $\%$ \\
\hline$\leq 1.000$ & 12 & 46 \\
\hline $1.001-2.000$ & 10 & 38 \\
\hline $2.001-3.000$ & 4 & 15 \\
\hline TOTAL & $\mathbf{2 6}$ & $\mathbf{1 0 0}$ \\
\hline
\end{tabular}


Gambar 1. Distribusi Kelompok Umur Responden

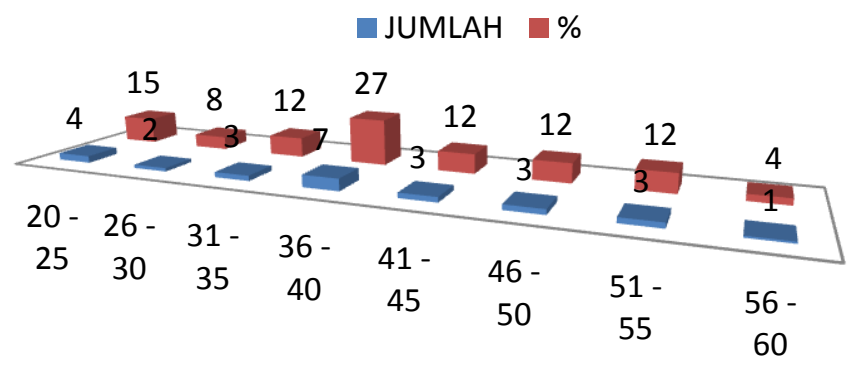

Gambar 2. Distribusi Jenis Pekerjaan Responden

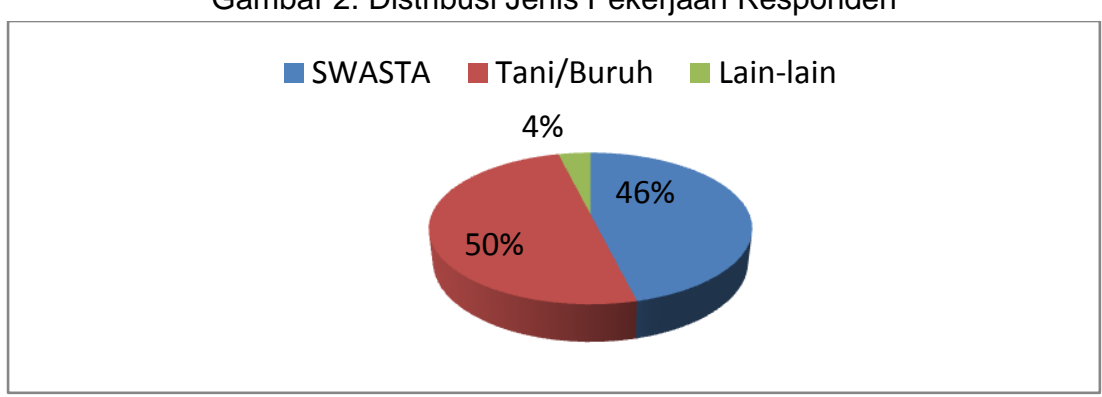

Gambar 3. Distribusi Tingkat Penghasilan Responden

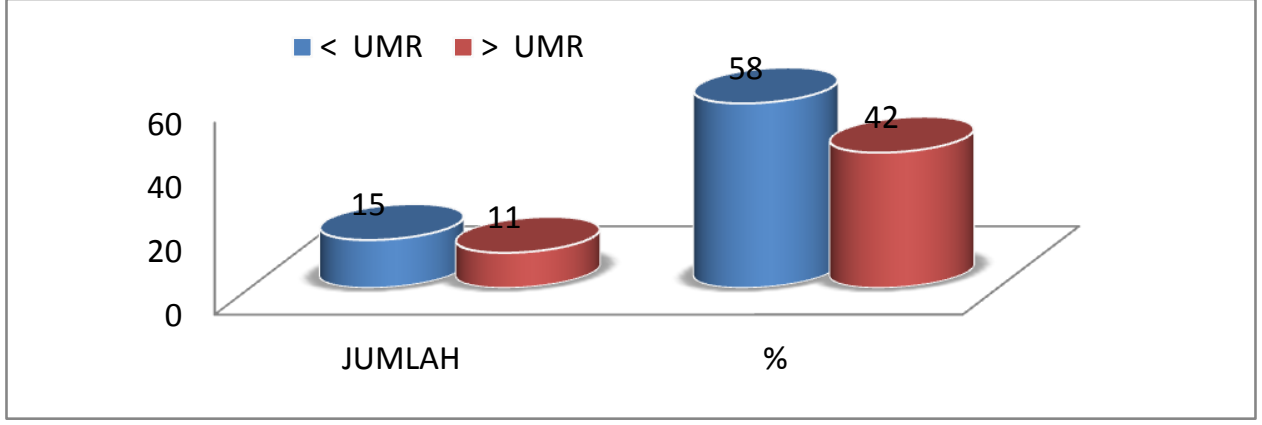

Gambar 4. Distribusi Frekuensi Kegiatan Mengikuti Penyuluhan

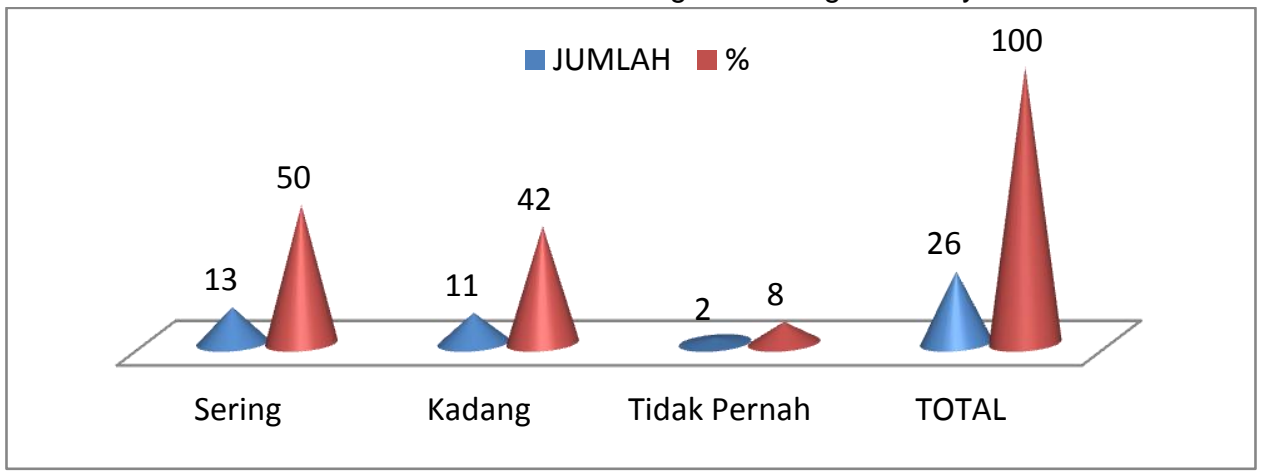


Gambar 5. Distribusi Frekuensi Konseling Kehamilan

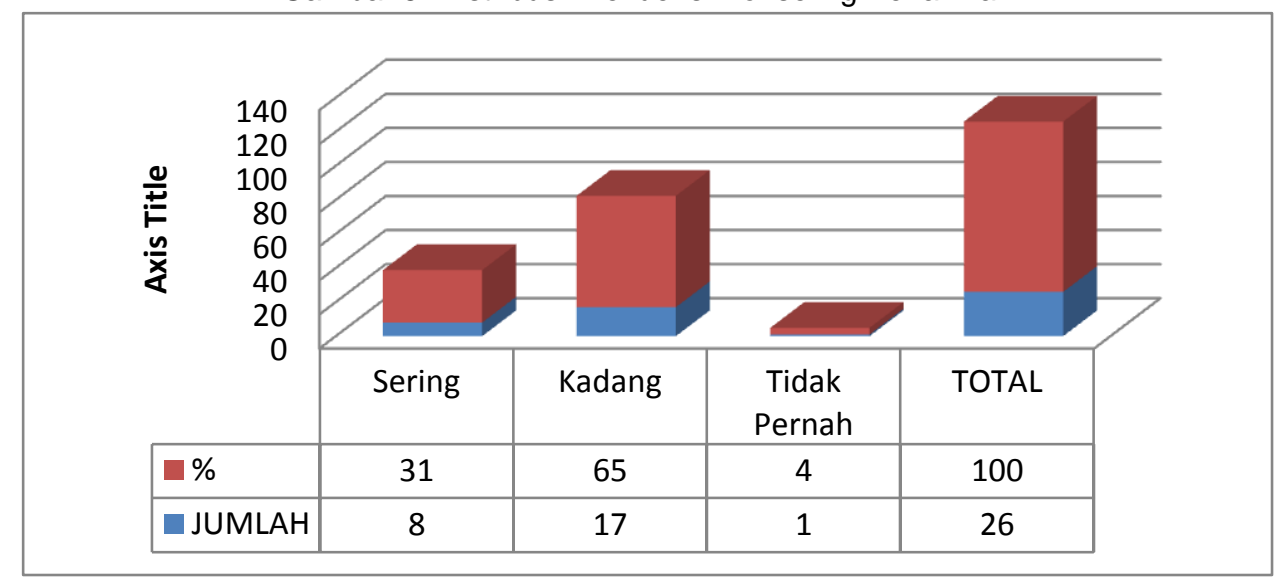

Gambar 6. Distribusi Frekuensi Pertemuan Kelas Ibu Hamil

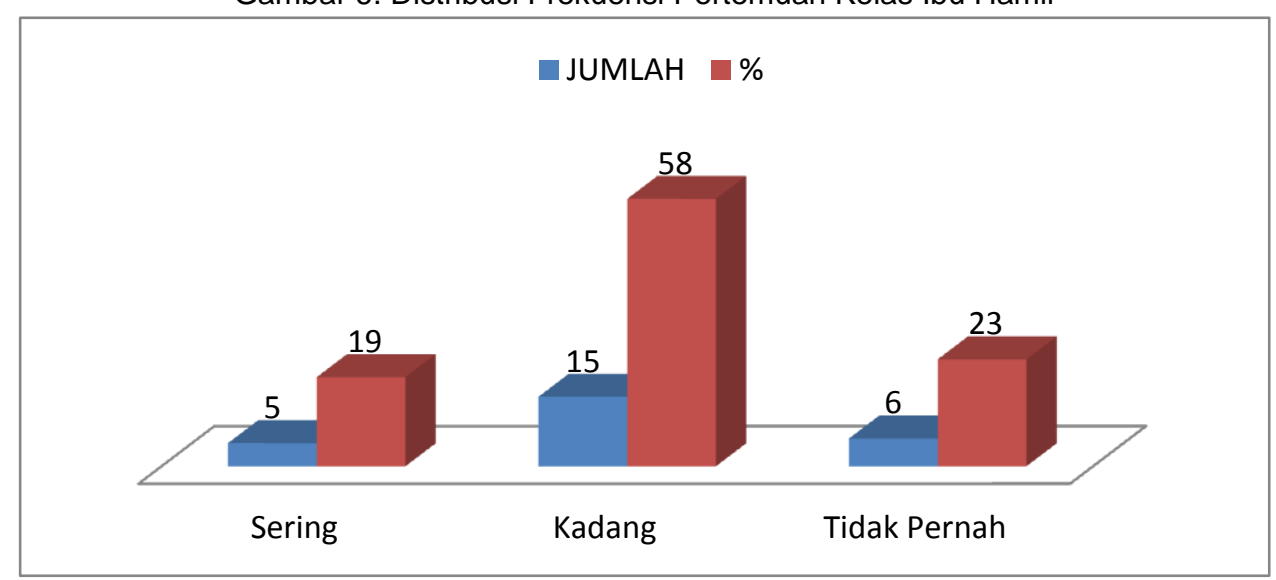

Gambar 7. Distribusi Frekuensi Pembinaan SPM Dibidang KIA

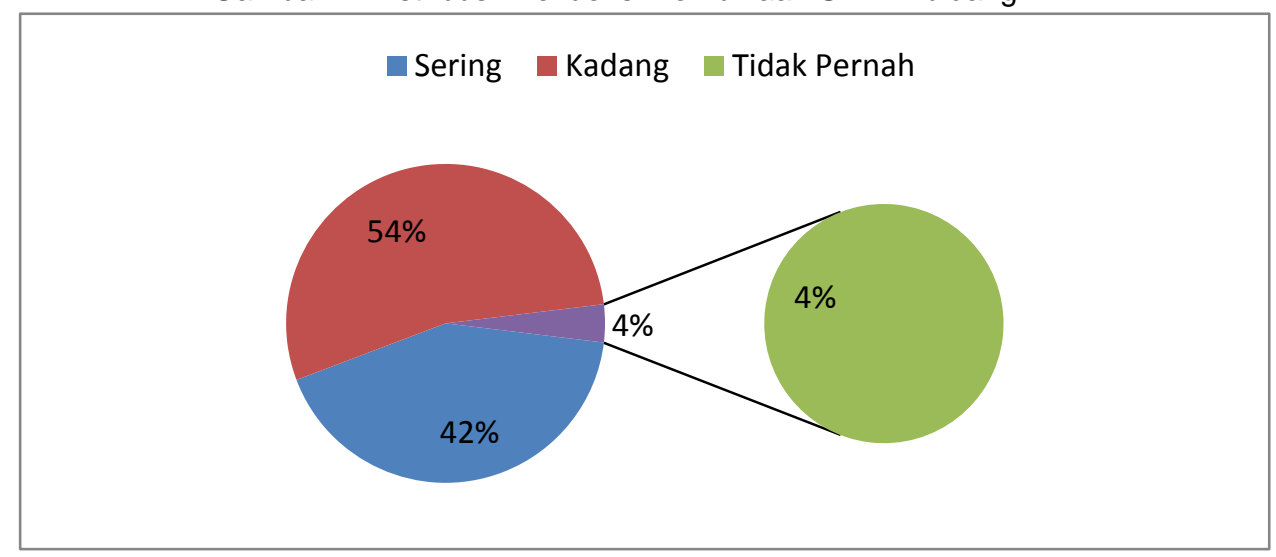


Tabel 4. Distribusi Responden Menurut Tingkat Pendidikan dan Sikap Suami

\begin{tabular}{cccc}
\hline \multirow{2}{*}{$\begin{array}{c}\text { Tingkat } \\
\text { Pendidikan }\end{array}$} & \multicolumn{2}{c}{ Sikap } & Jumlah \\
\cline { 2 - 3 } & Positif & Negatif & \\
\hline SD & 6 & 2 & 8 \\
\hline SMP & 11 & 0 & 11 \\
\hline SMA & 5 & 0 & 5 \\
\hline PT & 2 & 0 & 2 \\
\hline Jumlah & 24 & 2 & 26 \\
\hline
\end{tabular}

Hasil analisis hubungan antara Tingkat Pendidikan dengan Sikap Suami diperoleh bahwa sebanyak 6 orang (75\%) dari responden yang berpendidikan SD mempunyai sikap yang positif. Sedangkan diantara responden yang berpendidikan diatas SD seluruhnya (100\%) mempunyai sikap yang positif terhadap kegawatdaruratan istrinya.

Tabel 5. Distribusi Responden Menurut Jenis Pekerjaan dan Sikap Suami

\begin{tabular}{cccc}
\hline \multirow{2}{*}{$\begin{array}{c}\text { Jenis } \\
\text { Pekerjaan }\end{array}$} & \multicolumn{2}{c}{ Sikap } & Jumlah \\
\cline { 2 - 4 } & Positif & Negatif & \\
\hline Swasta & 13 & 13 & 13 \\
\hline Tani/buruh & 10 & 10 & 12 \\
\hline Lain-lain & 1 & 1 & 1 \\
\hline Jumlah & 24 & 24 & 26 \\
\hline
\end{tabular}

Hasil analisis hubungan antara Jenis Pekerjaan dengan Sikap Suami terlihat responden dengan pekerjaan swasta dan yang lain-lain semuanya mengungkapkan sikap yang positif. Ada 2 orang (16,7\%) dari 12 orang responden dengan pekerjaan Tani/Buruh yang mengungkapkan sikap yang negatif. Hasil uji statistik diperoleh nilai $p=0,283(p>\alpha)$ maka dapat disimpulkan bahwa tidak ada hubungan yang signifikan antara jenis pekerjaan dengan pengambilan sikap.

Tabel 6. Distribusi Responden Menurut Jenis Penghasilan dan Sikap Suami

\begin{tabular}{lll}
\hline Penghasilan & Sikap & Jumlah \\
\hline
\end{tabular}

\begin{tabular}{cccc}
\hline & Positif & Negatif & \\
\hline$<$ UMR & 14 & 1 & 15 \\
\hline$>$ UMR & 10 & 1 & 11 \\
\hline Jumlah & 24 & 2 & 26 \\
\hline
\end{tabular}

Hasil analisis hubungan antara status keuangan (penghasilan) dengan perilaku pengambilan sikap diperoleh data hasil analisis bahwa masing-masing satu narasumber mengambil sikap yang cenderung negatif atau kurang tepat dalam menghadapi keadaan istrinya apabila dalam kondisi gawat darurat dalam kehamilan atau menghadapi persalinannya.

Tabel 7. Distribusi Responden Menurut Pengetahuan dan Sikap Suami

\begin{tabular}{cccc}
\hline \multirow{2}{*}{ Pengetahuan } & \multicolumn{2}{c}{ Sikap } & \\
\cline { 2 - 3 } & Positif & Negatif & \\
\hline Kurang & 3 & 1 & 4 \\
\hline Cukup & 3 & 1 & 4 \\
\hline Baik & 18 & 0 & 18 \\
\hline Jumlah & 24 & 2 & 26 \\
\hline
\end{tabular}

Dari hasil analisis hubungan antara pengetahuan dan sikap suami dapat dilihat bahwa suami dengan pengetahuan yang baik seluruhnya (100\%) mengambil sikap yang positif. Sedangkan pada suami dengan pengetahuan kurang dan cukup terdapat masing-masing satu orang responden yang menambil sikap yang negatif. Hasil statistik diperoleh nilai $\mathrm{p}=0,870$ yang berarti $\mathrm{Ho}$ gagal ditolak yang berarti tidak hubungan yang signifikan antara pengetahuan dan sikap suami.

\section{PEMBAHASAN}

\section{Pengetahuan dan Sikap}

Variabel pengetahuan menjadi salah satu objek penelitian yang melalui tahapan uji pengetahuan dengan pengisian soal-soal dalam kuesioner penelitian. Nilai dari hasil test dengan menjawab pertanyaanpertanyaan dalam kuesioner memberikan variasi hasilnya mulai dari nilai 40 (kurang) 
sampai dengan baik. Penilaian ini berdasarkan teori yang ada.

Menurut Ircham (2008) penentuan tingkat pengetahuan responden dibagi dalam 3 kategori, yaitu baik, cukup dan kurang. Katagori baik, bila subjek mampu menjawab dengan benar 76\%-100\% dari seluruh pertanyaan. Katagori cukup, bila subjek mampu menjawab dengan benar $56 \%-75 \%$ dari seluruh pertanyaan. Katagori kurang, bila subjek mampu menjawab dengan benar 40\%-55\% dari seluruh pertanyaan.

Seperti halnya pengetahuan penilaian sikap juga dikelompokan menjadi dua katagori. Sikap dapat bersifat positif dan dapat pula bersifat negatif. Purwanto (1998) dalam Wawan dan Dewi (2011; h. 34) sikap positif, kecenderungan tindakan adalah mendekati, menyenangi, dan mengharapkan objek tertentu. Sikap negatif terdapat kecenderungan untuk menjauhi, menghindari, membenci, tidak menyukai objek tertentu. Penilaian sikap dalam penelitian ini dilihat dari jawaban responden akan 4 (empat) pilihan jawaban yang mengikat dalam kuesioner. Penilaian sikap positif bila responden menjawab minimal 3 pertanyaan yang sesuai, sedangkan untuk sikap negatif dinilai setidaknya responden menjawab 2 pertanyaan yang tidak sesuai dengan konsep kegawatdaruratan.

\section{Kegiatan Petugas Kesehatan (bidan) di Desa}

Mayoritas bidan di desa melakukan penyuluhan tentang persalinana dan cara mencari penolong dalam persalinan. Bidan yang sering melakukan kegiatan ini mencapai $50 \%$ dan ada 2 wilayah responden yang bidannya tidak pernah melakukan kegiatan ini. Konseling kehamilan termasuk kegiatan yang kadangkadang saja dilakukan oleh bidan di desa $(65 \%)$ padahal hal ini sangat menentukan untuk ibu hamil nantinya saat memutuskan atau menentukan tempat atau sarana kesehatan untuk menolong persalinannya dan penting untuk mengantar ibu hamil untuk melalui kehamilannya dengan sehat dan aman.

Kegiatan kelas hamil seperti hal nya konseling kehamilan sangat penting untuk ibu-ibu hamil bisa melalui kehamilannya dengan sehat dan persalinan yang lancar dan aman. Mayoritas dari responden manyampaikan kegiatan ini dilaksanakan hanya kadang-kadang saja dan termasuk paling banyak di kuesioner yang menyatakan tidak pernah.

Kegiatan peran serta masyarakat dalam kesehatan ibu dan anak sebenarnya akan sangat membantu program pemerintah dalam pelayanan kesehatan ibu dan anak tetapi kenyataannya hanya dilakukan kadang-kadang mayoritas di wilayah rumah responden. Seluruh program kesehatan akan sangat susah dilaksanakan apabila peran serta masyarakat tidak digali dan diberdayagunakan.

Analisa hubungan antara umur dengan sikap, pendidikan dengan sikap, pekerjaan dengan sikap, penghasilan dengan sikap, dan jarak dengan sikap diperoleh data bahwa seluruh $\mathrm{p}$-value lebih besar dari nilai alfa ( $p$ value $>\alpha, 0.05$ ) sehingga dapat disimpulkan bahwa seluruh variabel independen tidak menunjukan adanya pengaruh yang signifikan terhadap sikap yang dilakukan suami (responden).

\section{KESIMPULAN}

1. Jumlah responden paling banyak terdapat pada kelompok umur 36-40 tahun, bekerja, berpendidikan SMP, dengan penghasilan dibawah UMR, jarak ke tenaga/fasilitas kesehatan kurang dari $1 \mathrm{~km}$.

2. Sebagian besar pengetahuan suami tentang kegawatdaruratan obstetri pada kategori baik.

3. Hampir semua responden segera mencari pertolongan ke bidan jika terjadi kegawatdaruratan obastetri

4. Sebagian besar suami yang menganjurkan isteri untuk ke tenaga kesehatan jika terjadi kegawatdaruratan obstertri 
5. Tidak ada hubungan signifikan antara tingkat pendidikan, umur, pekerjaan, penghasilan dan pengetahuan dengan pengambilan sikap suami dalam menghadapi kegawatdaruratan obstertri

\section{DAFTAR PUSTAKA}

Bratakoesoema, Dinan S. 2013. Penurunan Angka Kematian lbu di Jawa Barat, Suatu Tantangan Bagi Insan Kesehatan Jawa Barat. Pidato Purnabakti di Universitas Padjajaran Bandung.

Campbell S, Lee C. 2000. Gampbell S, Lee C. Obstetric Emergencies. In : Campbell S, Lee C, editors. Obstetrics by Ten Teachers. 17th edition. Arnorld Publishers.

Chamberlain, Geoffrey, \& Phillip Steer. 1999. ABC of Labour Care. Published by BMJ Publishing Group, London

Departemen Kesehatan RI. 2013. Riset Kesehatan Dasar. Jakarta: Badan Penelitian dan Pengembangan Kesehatan Kementrian Kesehatan RI.

Dinas Kesehatan Jawa Barat. 2013. Profil Kesehatan Jawa Barat Tahun 2013.

Dorland. 2011. Kamus Kedokteran.
ICDDR. 1999. Intervention Update. Tersedia dalam www. icddr.org/mchr/intervention8/mt-vol 5 n.html, Health and Population Extension Division Vol 5.

Kuswardani. 2006. Informatika, 'Proses Pengambilan Keputusan' Artikel Teknik Informatika dan Sistem Informasi.

Lawn J, Rrian J, McCarthy, Susan Rae Ross. 2002. The Healthy Newborn, CDC, CCHI, The Health Unit Care.

Mayasari. 2005. Konsep Kebidanan : Prinsip Pengembangan Karier Bidan. Fakultas Kedokteran Universitas Padjajaran. Bandung.

Notoatmodjo, Soekidjo. 2003. Prinsip-prinsip Dasar IImu Kesehatan Masyarakat Cetakan Kedua. PT. Rineka Cipta. Jakarta.

Paramita dan Pratiwi. 2007. Persepsi Organisasi Masyarakat Tentang Konsep Peran Serta Masyarakat dan Kontribusi Organisasi Masyarakat Terkait Upaya Akselarasi Penurunan Angka Kematian lbu dan Angka Kematian Bayi. Buletin Penelitian Sistem Kesehatan Vol. 10 No. 4. Jakarta : Badan Litbangkes Kemenkes RI. 